\title{
Diet of the Red-footed Falcon (Falco vespertinus) in Cyprus during autumn migration
}

\section{Haralambos AlivizATos $^{1 *} \&$ Nikolaos KASSINIS ${ }^{2}$}

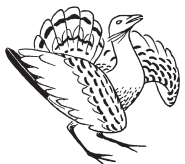

Received: March 21, 2021 - Revised: May 06, 2021 -Accepted: May 07, 2021.

Alivizatos, H. \& Kassinis, N. 2021. Diet of the Red-footed Falcon (Falco vespertinus) in Cyprus during autumn migration. - Ornis Hungarica 29(1): 120-125. DOI: 10.2478/orhu-2021-0009

\begin{abstract}
The diet of the Red-footed Falcon (Falco vespertinus) was studied at Akrotiri Peninsula, Cyprus, in October 2008, during the autumn migration. Based on 180 pellets collected that represented 3,066 prey items, the diet consisted exclusively of invertebrates, nearly all preys were insects. Winged ants (Hymenoptera, Formicidae) formed $94 \%$ of the diet by number of specimens and $76 \%$ of biomass. Beetles (Coleoptera), mainly Carabidae and Scarabaeidae, made up 5\% of the prey numbers but $22.5 \%$ of biomass. The other preys were made up by small numbers of earwigs (Dermaptera), true bugs (Hemiptera) and snails (Gastropoda).
\end{abstract}

Keywords: Akrotiri, ants, invertebrates, pellets, stopover

Összefoglalás A kék vércse (Falco vespertinus) táplálék-összetételét tanulmányozták 2008 októberében, az őszi vonulás idején a ciprusi Akrotiri-félszigeten. Az összegyüjtött 180 köpet 3066 zsákmányállat maradványait tartalmazta, ami kizárólag gerinctelenekből, szinte csak rovarokból állt. A zsákmány egyedszáma alapján a táplálékösszetétel 94\%-át hangyák alkották (Hymenoptera, Formicidae), amik a biomassza 76\%-át képezték. A bogarak (Coleoptera) közül fơként a futóbogárfélék (Carabidae) és a ganéjtúrófélék (Scarabaeidae) a zsákmány 5\%-át, a biomassza 22,5\%-át tették ki. A zsákmány fennmaradó részét kis számban fülbemászó (Dermaptera), félfedelesszárnyú (Hemiptera) és csiga (Gastropoda) fajok egyedei képezték.

Kulcsszavak: Akrotiri, gerinctelenek, hangyák, köpetek, pihenőhely

${ }^{1} 4$ Zaliki str., 11524 Athens, Greece,

${ }^{2}$ Game and Fauna Service, Nicosia, Cyprus

*corresponding author, e-mail: xaraaliv@otenet.gr

\section{Introduction}

The Red-footed Falcon (Falco vespertinus) is a small, gregarious, migratory falcon breeding in Eastern Europe, East to Central Asia and wintering in Southern Africa. It inhabits open lowland area, particularly steppes and farmland and breeds in abandoned nests of corvids (Cramp 1987). It is a species of global conservation concern, classified as near-threatened by IUCN, with a global population of 300,000-800,000 individuals (Ferguson-Lees \& Christie 2001), including 30,000-63,000 pairs in Europe (Keller et al. 2019).

Its diet has been studied mainly during the breeding season (e.g. Purger 1998, Szövényi 2015, Tulis et al. 2017), while there are no published studies of its diet during the species long distance trans-Saharan migration and during its stay in the winter quarters. In this study, data are presented on the diet of the species in Cyprus, during autumn migration. 
Cyprus is an important stopover site of the species, especially in autumn when there is usually a large passage, peaking from late September to mid-October (Kassinis \& Charalambidou 2020). Spring passage is very small in numbers compared to autumn migration. The study was based on pellets collected during field studies by the Game and Fauna Service personnel.

\section{Study area and methods}

The study area is located at Akrotiri peninsula, in the southernmost part of the island of Cyprus (Figure 1). This site is an internationally important stopover for the Red-footed Falcon, since hundreds to thousands birds are recorded each year (Zalles \& Bildstein 2000, Hellicar et al. 2014). During the years 2009-2019, systematic autumn counts ranged from 106-1,331 birds, with a peak at early October (Kassinis \& Charalambidou 2020) while the species is monitored annually during autumn migration. Red-footed Falcons stay and hunt in the peninsula in the extensive citrus plantations, open irrigated fields sown with clover and fallow areas in the vicinity of the wetlands. They are observed hunting from their roosting places, catching prey in flight, but also hunting and catching prey on open fields. Parts of the peninsula (especially citrus plantations and arable fields) are under considerable development pressures, with hundreds of hectares of agricultural land being lost.

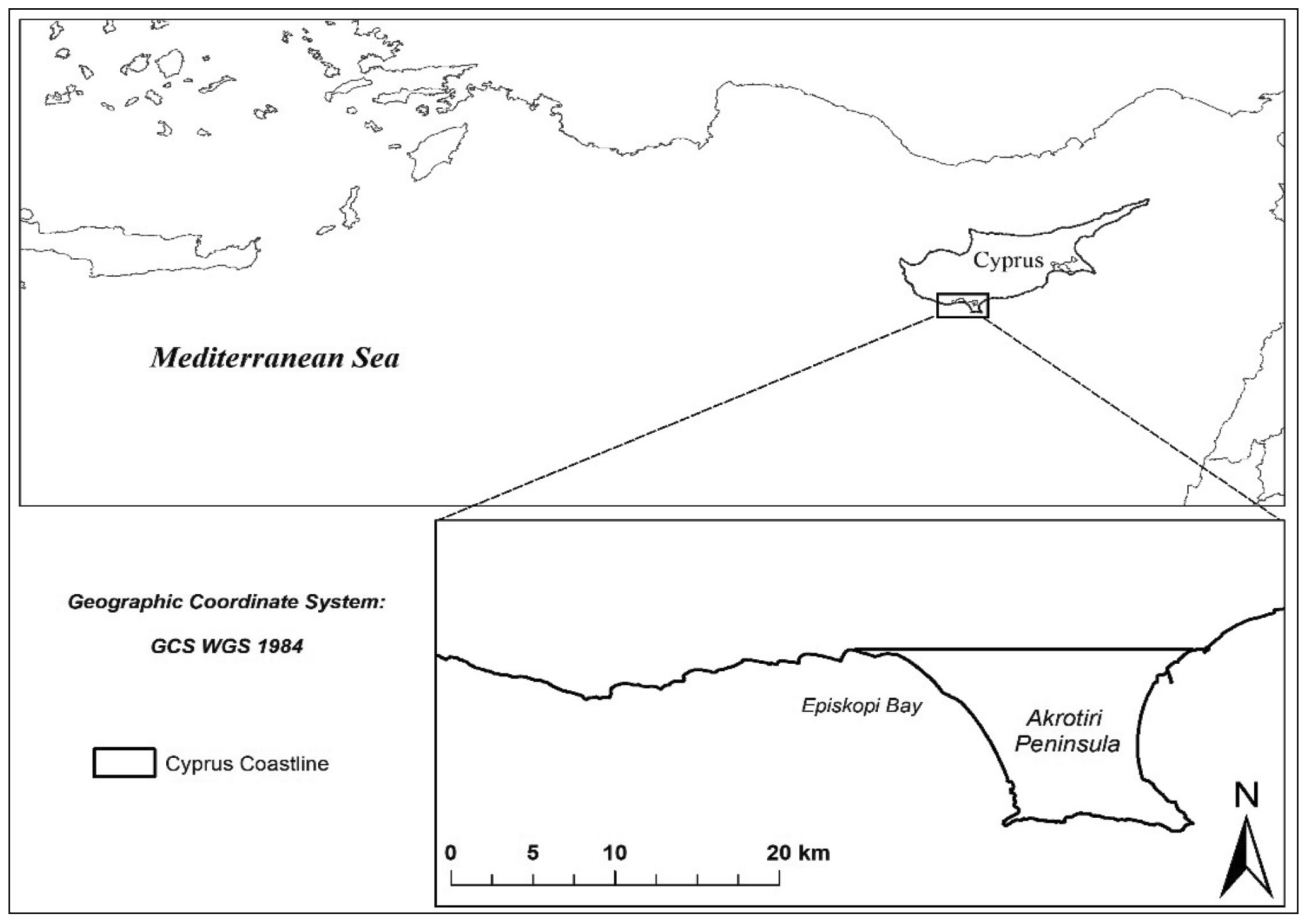

Figure 1. Cyprus map with Akrotiri Peninsula 1.ábra Ciprus térképe az Akrotiri-félszigettel 
Pellets were collected in October 2008 in citrus plantations under gregarious falcon nighttime roosts and under power lines crossing orchards and fields used by large groups of falcons during hunting. Only fresh and entire pellets were collected and were placed in plastic bags and sealed.

It is unlikely that any of the pellets collected belonged to other species. The pellet content was analyzed and the insects were identified to the family level with the help of the insect guide (Chinery 1993); no attempt was made to identify them to a lower level.

\section{Results}

In total, 180 pellets were analyzed, from which 3,066 prey items were identified. The diet consisted exclusively of invertebrates, nearly all prey were insects (Table 1).

Winged ants (Hymenoptera, Formicidae) made up 94\% of the prey item abundance and $76 \%$ of the biomass. Beetles (Coleoptera) were also important (5\% abundance, but $22.5 \%$

Table 1. Diet of the Red-footed Falcon at Akrotiri Peninsula, Cyprus

1. táblázat $A$ kék vércse táplálék-összetétele a ciprusi Akrotiri-félszigeten

\begin{tabular}{|l|c|c|c|}
\hline \multicolumn{1}{|c|}{ Prey categories } & $\begin{array}{c}\text { Number of prey } \\
\text { items }\end{array}$ & Items (\%) & Biomass (\%) \\
\hline MOLLUSCA & 3 & 0.1 & 0.4 \\
\hline Gastropoda indet. & 3 & 0.1 & 0.4 \\
\hline INSECTA & 3,063 & 99.9 & 99.7 \\
\hline Dermaptera & 16 & 0.5 & 0.2 \\
\hline Forficulidae & 16 & 0.5 & 0.2 \\
\hline Hemiptera & 1 & $<0.1$ & 0.1 \\
\hline Lygaeidae & 1 & $<0.1$ & 0.1 \\
\hline Coleoptera & 155 & 5.0 & 22.5 \\
\hline Carabidae & 95 & 3.1 & 12.5 \\
\hline Staphylinidae & 15 & 0.5 & 2.0 \\
\hline Alleculidae & 6 & 0.2 & 0.8 \\
\hline Tenebrionidae & 3 & 0.1 & 0.6 \\
\hline Elateridae & 1 & $<0.1$ & 0.1 \\
\hline Buprestidae & 1 & $<0.1$ & 0.3 \\
\hline Scarabaeidae & 18 & 0.6 & 4.8 \\
\hline Curculionidae & 10 & 0.3 & 1.3 \\
\hline Cerambycidae & 2 & $<0.1$ & 1.1 \\
\hline Coleoptera indet. & 2,891 & 0.1 & $<0.1$ \\
\hline Hymenoptera & 3,066 & 94.3 & 76.3 \\
\hline Formicidae & & & - \\
\hline Total & 4 & & \\
\hline
\end{tabular}


biomass), mainly Carabidae and Scarabaeidae, with some Staphylinidae, Curculionidae and others. The other preys were only a few earwigs (Dermaptera), true bugs (Hemiptera) and snails (Gastropoda), which biomass ranged between $0.01-2.00 \mathrm{~g}$, mean $0.12 \mathrm{~g}$.

\section{Discussion}

To our knowledge, this is one of the first studies on the diet of the Red-footed Falcon in a migration area, beside Golawski et al. (2017) from Poland. It is notable that its diet consisted exclusively of invertebrates, particularly winged ants. During breeding season the Redfooted Falcon was feeding mainly on larger insects (Orthoptera, Coleoptera and Odonata) and small vertebrates as well (mainly amphibians and small mammals). This is probably because larger prey is more economical to carry in the nests (Purger 1998, Palatitz et al. 2015, Szövényi 2015). The sample from Poland (Golawski et al. 2017) consisted mainly of larger insects (Orthoptera and Coleoptera) and only 3.2\% ants; there were also some small vertebrates (rodents). Thus, this sample was more similar to those in the breeding season than that of our study. Smaller but abundant prey can be consumed efficiently during migration, provided that is abundant enough, as it can be eaten very quickly. It can thus be assumed that winged ants were particularly abundant in the study area during the passage of the Red-footed Falcons, otherwise such small prey would not be so prevalent in the diet.

There are several studies of other small falcons that are largely insectivorous, at least outside the breeding season. The diet of the Amur Falcon (Falco amurensis) has been studied both in the breeding range (Mongolia) and in the wintering area (South Africa) (Schäfer 2003, Alexander \& Symes 2016). This species feeds mainly on arthropods (Coleoptera, Orthoptera, Isoptera, Solifugae and Hymenoptera) in the winter quarters, but takes more vertebrates when breeding.

The diet of the Lesser Kestrel (Falco naumanni) has been studied in Spain, Israel and Greece (Pérez-Granados 2010, Kopij \& Liven-Schulman 2012, Makri et al. 2016). In Spain and Israel, the diet was studied during the breeding season, and consisted mainly of large insects (mainly Orthoptera and Coleoptera), although in the former area small mammals made up about $50 \%$ of the diet by biomass. In Greece, pellets were collected before, during and after the breeding season. In the pre-breeding period, the main diet, by number, consisted of $43 \%$ Coleoptera, 32\% Hymenoptera (Formicidae) and 10\% Orthoptera. During the breeding season there were $69 \%$ Orthoptera, 25\% Coleoptera and 4\% Hymenoptera, while after breeding there were 50\% Orthoptera, 32\% Coleoptera and 11\% Hymenoptera. Thus, during breeding the Lesser Kestrels took mainly larger insects, while winged ants were taken at other seasons.

In an extensive study in Greece, Eleonora's Falcons (Falco eleonorae) were feeding mainly on insects before breeding, but switched to birds during the breeding season. The main insects taken were $45 \%$ cicadas (Homoptera), 35\% winged ants (Hymenoptera) and $16 \%$ Coleoptera (Xirouchakis et al. 2019). Thus, it appears that several small falcons may feed mainly on large insects and vertebrates during the breeding season (in particular, when have to carry food to the nest), but, outside breeding season may take a variety of small prey, 
such as arthropods. In many such cases, even small but abundant social insects (ants and termites) can be very profitable and important prey.

The results of this study on the diet of the Red-footed Falcon should be considered as preliminary, since, only one sample was collected during one migration season at Akrotiri Peninsula (Cyprus). More sampling throughout the migration period in other years might reveal a more diverse diet, affected by climatic or other conditions.

\section{Acknowledgements}

Many thanks to I. Charalambidou for her help during this study and to T. Theodorou for preparing the map. Also many thanks to the field staff of the Game and Fauna Service.

\section{References}

Alexander, J. \& Symes, C. T. 2016. Temporal and spatial dietary variation of Amur Falcons (Falco amurensis) in their South African nonbreeding range. - Journal of Raptor Research 50(3): 276-288. DOI: 10.3356/JRR15-16.110.

Chinery, M. 1993. Collins Field Guide, Insects of Britain and Northern Europe, $3^{\text {rd }}$ ed. - Collins

Cramp, S. (ed.) 1987. Handbook of the Birds of Europe, the Middle East and North Africa. The birds of the Western Palearctic, Vol. 2. Hawks to Bustards. - Oxford University Press

Ferguson-Lees, J. \& Christie, D. 2001. Raptors of the World. - Christopher Helm, London

Golawski, A., Kuprijanowicz, J., Szczypinski, P., Dombrowski, A., Mroz, E., Twardowski, M., Kielan, S., Amtczak, K., Pagorski, P. \& Murawski, M. 2017. Autumn irruptions of Red-footed Falcons Falco vespertinus in EastCentral Poland. - Polish Journal of Ecology 65(3): 423-433. DOI: 10.3161/15052249PJE2017.65.3.009

Hellicar, M. A., Anastasi, V., Beton, D. \& Snape, R. 2014. Important Bird Areas of Cyprus. - Nicosia: BirdLife Cyprus

Kassinis, N. \& Charalambidou, I. 2020. Autumn migration of the Red-footed Falcon, Falco vespertinus, at Akrotiri Peninsula, Cyprus 2009-2019 (Aves: Falconiformes). - Zoology of the Middle East 67(1): 19-24. DOI: 10.1080/09397140.2020.1865664.

Keller, V., Hernando, S., Voříšek, P., Franch, M., Kipson, M., Milanesi, P., Martí, D., Anton, M., Klvaňová, A., Kalyakin, M. V., Bauer, H-G. \& Foppen, R. P. B. 2020. European Breeding Bird Atlas 2. Distribution, Abundance and Change. - European Bird Census Council \& Lynx Edicions, Barcelona

Kopij, G. \& Liven-Schulman, I. 2012. Diet of the Lesser Kestrel, Falco naumanni, in Israel. - Zoology in the Middle East 55(1): 27-34. DOI: 10.1080/09397140.2012.10648914

Makri, M., Alivizatos, H., Vlachopoulos, K., Christakis, C., Kordopatis, P. \& Sfougaris, A. 2016. Study of the trophic habits of the Lesser Kestrel (Falco naumanni) during the breeding season in Thessaly plain. $-8^{\text {th }}$ Panhellenic Ecological Conference, Poster Presentation (in Greek)

Palatitz, P., Solt, S., Horváth, E. \& Kotymán, L. 2015. Hunting efficiency of Red-footed Falcons in different habitats. - Ornis Hungarica 23(1): 32-47. DOI: 10.1515/orhu-2015-0003

Pérez-Granados, C. 2010. Diet of adult Lesser Kestrels Falco naumanni during the breeding season in Central Spain. - Ardeola 57(2): 443-448.

Purger, J. J. 1998. Diet of Red-footed Falcon Falco vespertinus nestlings from hatching to fledging. - Ornis Fennica 75(4): 185-191.

Schäfer, S. 2003. Study of a Mongolian breeding population of the Amur Falcon (Falco amurensis Radde, 1863). Unpublished Dipl. Biol. Thesis, Haale/Saale, Germany: Martin-Luther Universität Halle-Wintenberg

Szövényi, G. 2015. Orthopteran insects as potential and preferred preys of the Red-footed Falcon (Falco vespertinus) in Hungary. - Ornis Hungarica 23(1): 48-57. DOI: 10.1515/orhu-2015-0004

Tulis, F., Slobodnik, R., Langaf, V., Noga, M., Krumpàlovà, Z., Šustek, Z. \& Krištìn, A. 2017. Diet composition of syntopically breeding falcon species Falco vespertinus and Falco tinnunculus in south-western Slovakia. Slovak Raptor Journal 11: 15-30. 
Xirouchakis, S., Alivizatos, H., Georgopoulou, E., Dimalexis, A., Latsoudis, P., Portolou, D., Karris, G., Georgiakakis, P., Fric, J., Saravia, V., Barboutis, C., Bourdakis, S., Kakalis, E., Kominos, T. \& Simaiakis, S. 2019. The diet of Eleonora's Falcon (Falco eleonorae) in the Aegean archipelago (Greece). - Journal of Natural History 53(29): 1767-1785. DOI: 10.1080/00222933.2019.1668978

Zalles, J. I. \& Bildstein, K. L. (eds.) 2000. Raptor Watch: A global directory of raptor migration sites. - Cambridge, UK: BirdLife International; and Kempton, PA, USA: Hawk Mountain Sanctuary (BirdLife Conservation Series No. 9)

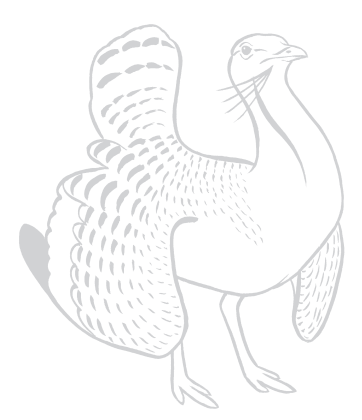

